\title{
Estudo anatômico e artroscópico do ligamento femoropatelar medial
}

Anatomic and arthroscopic study of the medial femoropatellar ligament

\author{
Gilberto Luis Camanho $^{1}$,Alexandre de Christo Viegas ${ }^{2}$
}

\section{RESUMO}

Os autores estudaram em joelhos de 11 cadáveres a presença do ligamento femoropatelar medial.Em 6 joelhos o estudo foi anatômico por dissecção e secção seriada das peças anatômicas.Em 5 joelhos o estudo foi artroscópico pela visibilização nos joelhos do ligamento encontrado nos seis joelhos estudados anatomicamente.

Em todas as peças anatômicas foi possível a dissecção da estrutura ligamentar descrita como o ligamento femoropatelar medial e nos cinco joelhos estudados sob visão artroscópica a visibilização e identificação do ligamento foi evidente .

Descritores: J oelho; Artroscopia; Traumatismos do joelho.

\section{INTRODUÇÃO}

A luxação aguda da articulação femoropatelar é um evento pouco freqüente. Ocorre em conseqüência de traumas resultantes de uma associação de movimentos rotacionais com graus variáveis de flexão do joelho.

A história clínica com o relato do trauma, o falseio com dore a hemartrose é comum à maioria das lesões agudas de joelho, nas quais o exame clínico é difícil pela presença de dor e do espasmo da musculatura, que impedem uma adequada movimentação da articulação, que possibilitaria um diagnóstico clínico preciso.

Hughston et al. ${ }^{(6)}$, em 1974, relatam que a luxação femoropatelar aguda é a causa mais freqüente de erro no diagnostico da avaliação do joelho agudo.

O tratamento da luxação femoropatelar aguda é ainda controverso pois alguns autores confundem o tratamento da luxação com o realinhamento do aparelho extensor.

\section{SUMMARY}

The authors studied in the knees of 11 cadavers the presence of medial femoropatellar ligament. In 6 knees the study was anatomical, with dissection and serial sectioning of the anatomic pieces. In 5 knees the study was arthroscopic, by the vizibilization, in the knees, of the ligament found in the six knees that were anatomically studied.

In all the anatomic pieces it was possible to dissect the ligament structure described as the medial femoropatellar ligament and in the five knees arthroscopically studied, the visibilization and identification of the ligament was evident.

Key Words: Knee; Arthroscopy; Knee injuries.

\section{INTRODUCTION}

The acute dislocation of the femoropatellar joint is not a frequent event. It occurs as a consequence of traumas resulting from an association of rottaional movements with varying degrees of knee bending.

A clinical history including the report of the trauma, the painful misstep, and hemarthrosis, is common to most acute knee injuries where a clinical examination is hard to perform due to the presence of pain and muscle spasms, preventing the joint from moving appropriately, something that would facilitate a precise clinical diagnosis.

In 1974 Hughston et al(6) reported that acute femoropatellar dislocation is the most frequent cause of diagnostic error in the evaluation of acute knee injuries.

The treatment of acute femoropatellar dislocation is still controversial, since some authors confuse the treatment for luxation with the realignment of the extensor apparatus.
Trabalho realizado no Laboratório de Artroscopia do Instituto de Ortopedia e Traumatologia do Hospital das Clinicas da Faculdade de Medicina da Universidade de São Paulo

1 - Professor associado da FMUSP

2 - Mestre em Ortopedia pela FMUSP

Endereço para correspondência: Rua Bennet 841 - CEP 05464-010 - São Paulo - São Paulo Trabalho recebido em 03/03/2003. Aprovado em 20/05/2003
This study was performed in the Laboratory of Arthroscopy, Institute of Orthopedics and Traumatology, Hospital das Clinicas, Faculty of Medicine, University of Sao Paulo, Sao Paulo, SP, Brazil.

1 - Associate Professor, Faculty of Medicine, University of Sao Paulo (FMUSP) 2 - Master's Degree in Orthopedics from FMUSP

Mail address: Rua Bennet, 841 - São Paulo, SP 05464-010 - Brazil 
A partir dos anos 90 alguns autores ${ }^{(1,2,8)}$ relatam seus resultados no tratamento da luxação aguda da patela, pelo reparo do ligamento femoropatelar medial LFPM descrito por Warren e Marshall(10) em 1979.

o conhecimento anatômico e biomecânico deste ligamento e a sua reparação, trouxe resultados melhores e mais uniformes ao tratamento cirúrgico da luxação aguda da patela ${ }^{(1,9)}$.

0 objetivo do presente trabalho é descrever anatomicamente o LFPM e descrever também o seu aspecto visibilizado por artroscopia, para possibilitar a sua reparação por via artroscópica no tratamento da luxação femoropatelar aguda .

\section{MATERIAL E MÉTODO}

Utilizamos para o presente 11 joeIhos de cadáveres armazenados no Laboratório de Artroscopia do Instituto de Ortopedia e Traumatologia do Hospital das Clinicas da FMUSP. Estes joelhos haviam sido utilizados para treinamento de meniscectomias e reparações ligamentares ,porém nenhum deles tinha qualquer tipo de abordagem cirúrgica no aparelho extensor do joelho .

Dividimos o estudo em dois: 0 anatômico e o artroscópico,pois os joeIhos estudados no estudo anatômico foram dissecados ou cortados impedindo o estudo artroscópico .

\section{ESTUDO ANATOMICO}

Utilizamos para o presente trabaIho seis joelhos de cadáveres congelados.

Inicialmente dissecamos 0 aspecto medial do joelho expondo o músculo vasto medial e sua inserção na porção medial da patela.

Desinserimos o m-vasto medial e verificamos que após a desinserção da patela há um espaço entre o m.vasto medial e cápsula articular facilmente dissecável, não havendo nenhuma inserção anatomicamente detectável entre o músculo e a cápsula articular, neste nível.

Palpa-se nitidamente um espessa-

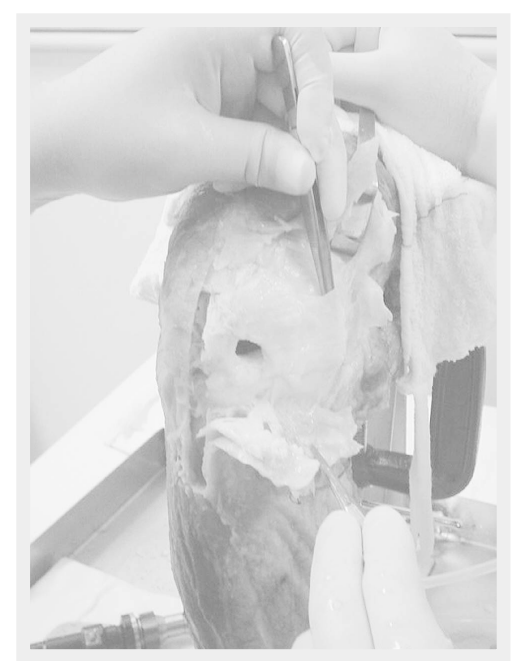

Figura 1 - Aspecto medial do joelho com o ligamento femoropatelar medial sendo levantado pelo instrumento metálico.

Figure 1 - Medial aspect of knee with the medial femoropatellar ligament being lifted by the metal instrument.



Figura 2 - Ligamento femoropatelar medial desinserido do epicôndilo medial.

Figure 2 - Medial femoropatellar ligament disinserted from the medial epicondyle.

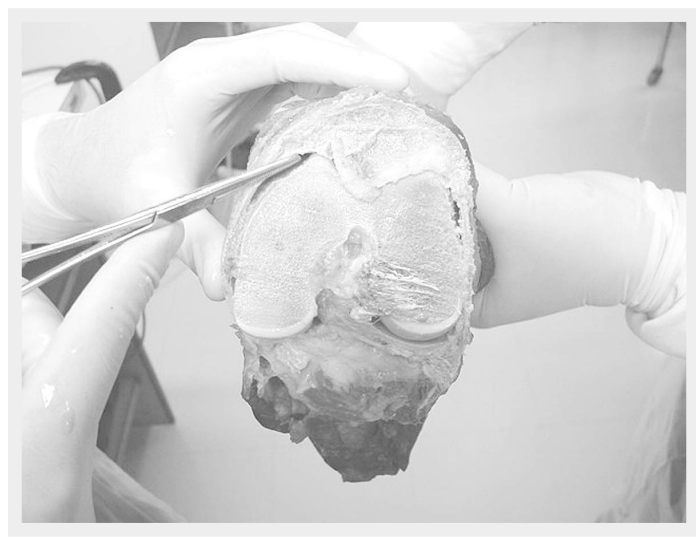

Figura 3 - Ligamento femoropatelar medial desinserido da patela.

Figure 3 - Medial femoropatellar ligament disinserted from the patella.
After the decade of 1990 some authors $(1,2,8)$ reported their findings in the treatment of acute patellar dislocation by repairing the medial femoropatellar ligament (MFPL) as described by Warren and Marshall(10) in 1979.

The anatomical and biomechanical knowledge of this ligament and its repair led to better and more uniform results in the surgical treatment of acute patellar dislocation ${ }^{(1,9)}$.

The purpose of this study is to anatomically describe the MFPL, besides describing its aspect as visibilized by arthroscopy, in order to make it possible to repair it arthoscopically in the treatment of acute femoropatellar luxation.

\section{MATERIAL AND METHOD}

For this study we used 11 knees from cadavers stored in the Laboratory of Arthroscopy of the Institute of Orthopedics and Traumatology of the Hospital das Clínic as of the Faculty of Medicine of the University of Sao Paulo. The knees had already been used in the training of meniscectomies and ligament repair, although none of them had any type of surgical approach in the knee extensor apparatus.

We divided the study into two substudies, one anatomic and one arthroscopic, since the knees studied in the anatomic study had been dissected or cut and could not be studied arthroscopically.

\section{ANATOMIC STUDY}

In this study we used six knees from frozen cadavers.

Initially we dissected the knee medial aspect in order to expose the medial vastus muscle and its insertion into the medial portion of the patella.

Then we disinserted the medial vastus muscle and found out that after the disinsertion of the patella there is a space between the medial vastus muscle and the joint capsule that can be dissected very easily, with no anatomically detectable insertions between the muscle and the knee joint capsule at this level.

A thickening of the posterior joint 
mento da cápsula articular posterior ao m-vasto medial que dirige-se do bordo medial da patela até a região do epicôndilo medial .A identificação desta estrutura ocorreu nitidamente em todos os seis joelhos estudados.

A dissecção desta estrutura permite identificar um ligamento que origina-se no bordo medial superior e médio da patela e insere-se no epicôndilo femoral anteriormente a inserção do ligamento colateral medial. (Figuras $1,2,3,4$ e 5 )

\section{ESTUDO ARTROSCÓPICO}

Utilizamos 5 joelhos de cadáveres congelados para o estudo artroscópico.

Realizamos a artroscopia por metodologia convencional.

Pudemos visibilizar, por transparência da membrana sinovial as fibras horizontais do ligamento dirigindo-se do bordo medial da patela até o epicôndilo medial.

Fizemos em todos os casos a sinovectomia medial extensa utilizando para tal um "shaver" com lamina própria para sinovectomia.

Após a sinovectomia a visualização e a palpação do LFPM tomou-se evidente.

Trata-se de uma estrutura com aspecto tendinoso que dirige-se da face medial da patela até a região mais anterior do epicôndilo medial.

A sua visibilizaçào foi possível em todos os 5 joelhos estudados. (Figuras 6 e 7 )

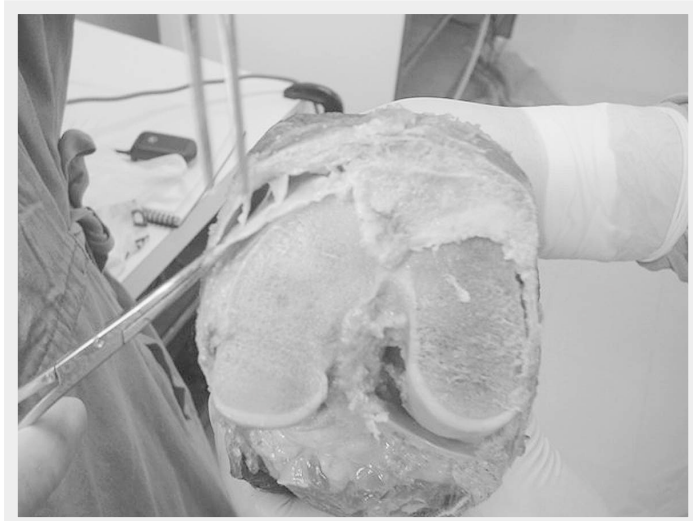

Figura 4 - Corte axial do joelho demonstrando o ligamento femoropatelar medial.

Figure 4 - Axial section of knee, showing the medial femoropatellar ligament.

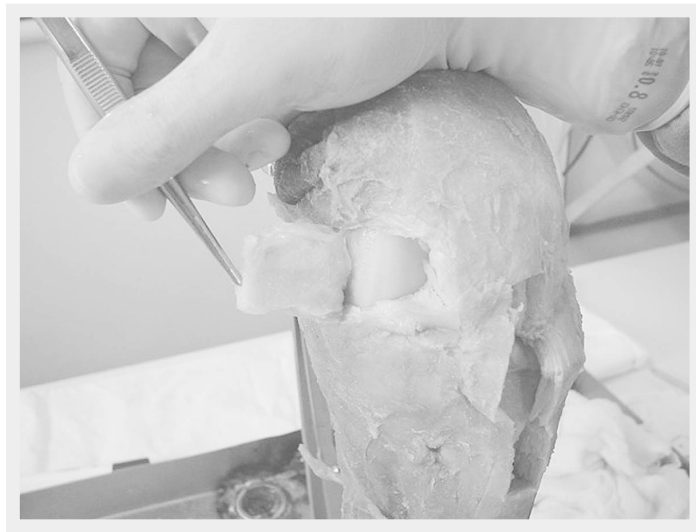

Figura 5 - Corte axial do joelho demonstrando o ligamento femoropatelar medial e traves de inserção entre o ligamento e a face posterior da porção distal do músculo vasto medial.

Figure $\mathbf{5}$ - Axial section of knee, showing the medial femoropatellar ligament and the insertion locks between the ligament and the posterior face of the distal portion of the medial vastus muscle. capsule to the medial vastus muscle that goes from the patellar medial border to the medial epicondyle region could be easily palpated. This structure could be clearly identified in all six knees studied.

The dissection of this structure allows the identification of a ligament that originates in the superior and median patellar medial borders and is inserted into the femoral epicondyle before the insertion of the medial collateral ligament. (Figures 1,2,3,4 and 5)

\section{ARTHROSCOPIC STUDY}

In our arthroscopic study we used 5 knees from frozen cadavers.

The arthroscopy was performed by the conventional method.

By transparency of the synovial membrane we could observe the horizontal fibers in the ligament going from the patellar medial border to the medial epicondyle.

We performed in all cases the extense medial synovectomy using a shaver with an appropriate blade for synovectomy.

After the synovectomy the MFPL could be clearly seen and palpated.

This tendinous-looking structure goes from the patellar medial face to the more anterior region of the medial epicondyle and could be clearly seen in all 5 knees studied. (Figures 6 and 7)



Figura 6 - Imagem obtida por visibilização artroscópica da região medial para patelar do joelho,pós sinovectomia, demonstrando o LFPM

Figure 6 - Image obtained by arthroscopic visibilization of the medial parapatellar knee region after the synovectomy, showing the LFPM.

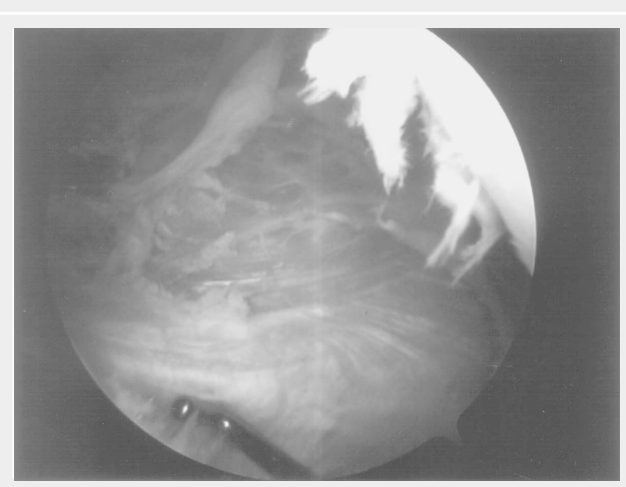

Figura 7 - Imagem obtida por visibilização artroscópica da região medial para patelar do joelho,pós sinovectomia, com o gancho de palpação demonstrando o LFPM

Figure 7- Image obtained by arthroscopic visibilization of the medial parapatellar knee region after the synovectomy, with the palpation hook, showing the MFPL. 


\section{DISCUSSÃO}

A motivação de realizarmos um estudo anatômico foi procurar padronizar uma técnica de sutura e reparo do LFPM ,para tratamento da luxação femoropatelar aguda.

Warren e Marshall(10) em 1979, após estudo anatômico detaIhado do lado medial do joelho descrevem o ligamento femoropatelar medial. Este ligamento é mais profundo que o músculo vasto medial, originando-se no epicôndilo femoral medial e inserindo-se no bordo medial da patela.

O ligamento femoropatelar medial não consta da nomina anatômica.

Hughston et al. ${ }^{(7)}$, em 1984 , referem-se ao ligamento pateloepicondilar como suporte estático da estabilidade femoropatelar. Consideram, no seu trabalho, o vasto medial obliquo como o mais importante estabilizador dinâmico da patela.

Relatam a lesão do músculo vasto medial com o ligamento chamado pelos autores de pateloepicondilar, por desinserção no epicôndilo em algumas luxações agudas da patela.

Pela descrição dos autores parece que os mesmos estão se referindo ao ligamento femoropatelar medial descrito por Warren e Marshall(10).

Baseamos nesta descrição inicial para localizarmos o LFPM nos cadáveres estudados e encontramos em todos o ligamento nitidamente presente.

Feller et al. ${ }^{(5)}$,em 1993 ,estudaram joelhos de 20 cadáveres e confirmaram a existência do ligamento femoropatelar medial em todos.

Colan et al.(3), em 1993, estudaram 25 cadáveres congelados e reconheceram o ligamento femoropatelar medial em todos.

Fizeram estudos biomecânicos que constituíam em tentar luxar a patela lateralmente, para estudar quais as principais estruturas que impediam esta luxação. Verificaram que a força correspondente a integridade do ligamento femoropatelar medial é responsável por $53 \%$ de toda a força de contensores mediais.

Desio et al. ${ }^{(4)}$ em 1998 fizeram um interessante estudo em 9 cadáveres humanos. Provocavam a luxação da patela com uma máquina que aplicava uma força lateral de $200 \mathrm{~N}$ com o joelho fletido a 20 graus. Realizavam a secção seletiva das estruturas de contenção seguida do teste mecânico.

As estruturas seccionadas foram, na ordem:

Retináculo lateral ,ligamento femoropatelar medial(LPFM), retináculo medial, ligamento patelo tibial medial, ligamento patelo meniscal medial.

0 estudo demonstrou que o ligamento patelo femoral medial é responsável por $60 \%$ da contenção da luxação lateral da patela .

A visibilizaçào por artroscopia confirmou o aspecto encontrado no estudo anatômico e demonstrou ser possível a reconstrução deste ligamento em toda a sua extensão por via artroscópica. Não há na literatura pesquisada referencia a reconstrução artroscópica do LFPM .

\section{DISC USSION}

The reason that led us to perform an anatomic study was to try to standardize a technique of suture and repair of the MFPL for the treatment of acute femoropatellar luxation.

After performing a detailed anatomic study of the medial side of the knee, Warren and Marshall(10) described in 1979 the medial femoropatellar ligament. This ligament is deeper than the medial vastus muscle, originates in the medial femoral epicondyle and is inserted into the patellar medial border.

The medial femoropatellar ligament is not included in the nomina anatomica.

In 1984 Hughston et al(7) referred to the patella-epicondyle ligament as a static support of the femoropatellar stability. In their study, the authors consider the oblique medial vastus the most important dynamic stabilizer of the patella.

They report the injury of the medial vastus muscle with the ligament (which the authors call patella-epicondyle) by disinsertion in the epicondyle in some acute patellar luxations.

According to the description given by the authors, its seems that they are referring to the medial femoropatellar ligament described by Warren and Marshall(10).

We used this initial description to locate the MFPL in the cadavers studied, and found out that this ligament was clearly present.

In 1993 Feller et al ${ }^{(5)}$ studied the knees of 20 cadavers, having confirmed the presence of the medial femoropatellar ligament in all of them.

In 1993 Colan et al ${ }^{(3)}$ studied 25 frozen cadavers and also recognized the medial femoropatellar ligament in all of them.

Those authors peformed biomechanical studies that consisted of trying to laterally luxate the patella in order to investigate which among the main structures would prevent luxation. They found out that the force corresponding to the integrity of the medial femoropatellar ligament is responsible for $53 \%$ of all the force of the medial contention structures.

In 1998 Desio et al ${ }^{(4)}$ performed an interesting study in 9 human cadavers where they provoked the patellar dislocation using a machine that would apply a lateral force of $200 \mathrm{~N}$ with the knee bent to 20 degrees. Then they performed the selective sectioning of the contention structures, followed by a mechanical test

The sectioned structures followed the order below:

Lateral retinaculum, medial femoropatellar ligament (MFPL), medial retinaculum, medial patellotibial ligament, and medial patellomeniscal ligament.

The authors showed that the medial patello-femoral ligament is responsible for $60 \%$ of the contention of the patellar lateral luxation.

The visibilization by arthroscopy has confirmed the aspect found in our anatomic study and showed that it is possible to arthroscopically reconstruct this ligament in all its extension. A search in the literature did not reveal any arthroscopic reconstruction of the MFPL.

In 1996 Sallay et al ${ }^{(9)}$ studied 23 patients with acute patellar 
Sallay et al.(9) em 1996, estudaram 23 pacientes com luxação aguda da patela. Deste grupo 16 pacientes foram submetidos a artroscopia, seguida de exploração cirúrgica do lado medial do joelho.

Em 15 dos 16 pacientes foi encontrada lesão do ligamento femoropatelar medial (LFPM), que foi suturada .Estas lesões ocorreram,na maioria dos casos, na inserção do LFPM no epicôndilo femoral. Em alguns casos foi necessário o uso de ancoras para a sutura de reinserção do LFPM.

Os pacientes foram acompanhados por pelo menos 2 anos .Nenhum paciente que teve o LFPM reparado apresentou recorrência da luxação da patela .

Acreditamos que após este estudo anatômico artroscópico a reparação do LFPM será possível por via artroscópica. luxation. Sixteen of these patients were subjected to arthroscopy followed by surgical probing of the medial side of the knee.

Of the 16 patients, 15 presented a medial femoropatellar ligament injury that was sutured. In most cases these injuries occurred in the insertion of the MFPL into the femoral epicondyle. In some cases it was necessary to use suture anchors in the reinsertion of the MFPL.

The patients were monitored for a minimum of 2 years and none of them who had their MFPLs repaired presented a recurrence of patellar luxation.

We believe that after this anatomic-arthroscopic study, it will be possible to repair the MFPL arthroscopically.

\section{REFERÊNCIAS BIBLIOGRÁFICAS}

1. Ahmad CS, Stein BES, Matuz D, Henry J H. Immediate surgical repair of the medial patellar stabilizers for acute patellar dislocation. A review of eight cases. Am J Sports Med 28:804-810, 2000.

2. Atkin DM, Fithian DC, Marangi KS, Stone ML, Dobson BE, Mendelnsohn $C$. Characteristics of patients with primary acute patellar dislocation and their recovery within 6 months of injury. Am J Sports Med 28:472-479, 2000.

3. Conlan T, Grath WP, Lemons J E. Evaluation of the medial softtissue restraints of the extensor mechanism of the knee. J Bone J oint Surg Am 75:682-693, 1993.

4. Desio SM, Burks RT, Bachus KN. Soft tissue restraints to lateral patellar translation in the human knee. Am J Sports Med 26:5965, 1998.

5. Feller J A, Feagin J A, Garret WE, J r. The medial patello femo- ral ligament revisited: an anatomical study. Knee Surg Sports Traumatol Arthrosc 1:184-6, 1993.

6. Hughston J C, Andrews J R, Cross MJ . The injured knee. J Med Assoc Ga, 63:362-368,1974.

7. Hughston J C, Walsh WM, Puddu G. Patellar subluxation and dislocation. Philadelphia:Saunders, 1984. 198p.

8. Nomura E. Classification of lesions of the medial patello-femoral ligament in patellar dislocation. Int Orthop 23:260 263,1999.

9. Sallay PI, Poggi J , Speer KP, Garret WE. Acute dislocation of the patella. A correlative pathoanatomic study. Am J Sports Med 24:52-60, 1996.

10. Warren LF, Marshall J L. The supporting structures and layers on the medial side of the knee; an anatomical analysis. J Bone J oint Surg Am 61:56-62, 1979 